\title{
Use of Internet/Web Resources by the Faculty Members and Students of Engineering College Libraries in Sri Venkateswara University Area
}

\author{
Dr. T. Raghunadha Reddy \\ Librarian, Sri Venkateswara College of Engineering \\ and Technology, \\ Chittoor, Aandra Pradesh, India
}

\author{
V. Pulla Reddy \\ Emeritus Professor, \\ Department of Library \& Information Science, \\ S. V. University, Tirupathi, Aandra Pradesh, India
}

\section{ABSTRACT}

The aim of this study is to analyze the use of the Internet and related issues among the faculty members and the students of engineering college libraries in Sri Venkateswara University Area. A well structured questionnaire was distributed among the 1314 faculty members and the students under study. The present study demonstrates and elaborates the various aspects of Internet use, such as availability of Internet facility, most frequently used place of Internet used, frequency of Internet use, experience in using Internet, type of Internet browsers used, preferred search engines, use of Internet services, satisfaction with Internet facility, problems faced by the users. It was found that the Internet has become a vital instrument for teaching, research and learning process for these respondents. Some suggestions are set forth to make the services more beneficial for the academic community of the engineering colleges under study.

KEYWORDS: Internet, Internet browsers, Search engine

\section{INTRODUCTION}

Today the Internet plays a significant role in the teaching, research and learning process. It is understood that the engineering students and faculty members in India feel more dependent on the Internet for their class assignments and for the latest information for their subject areas than conventional resources of information. Engineering faculty also feel a bit handicapped in updating their knowledge base quickly without using the Internet for their research and class room teaching activities.

Internet has emerged as the most powerful medium for storage and retrieval of information. It works round the clock and connects every nook and corner of the globe. With an unprecedented growth in the quantum of knowledge worldwide and the easy accessibility, Internet has become an unavoidable necessity for every institution of higher learning and research.

\section{REVIEW OF LITERATURE}

A study made by Sreenivasulu and Nagabhushanam ${ }^{1}$ examines the use of Internet and online databases by the students of National Institute of Fashion Technology, Kannur. Data was collected using a questionnaire. The present study evaluates the use of Internet, search engines and online databases, etc. Suggestions have been given to make the better use of Internet and online databases for the academic purpose. The results also indicated that all IT based resources and facilities are not sufficient to the users.

A study made by Madhuri ${ }^{2}$ deals with the use of Internet by the students of the engineering colleges in and around of Tirupati, Andhra Pradesh, India. This study examines the frequency of Internet use, purpose of using the Internet, use of different Internet services, and impact of Internet on engineering education. Questionnaire tool was used for collection of data from the engineering students. Out of 180 questionnaires distributed, 140 filled-in questionnaires were received. The results of the study reveal that $81.42 \%$ of the students informed that their colleges are providing sufficient computer systems in their labs; $78.28 \%$ of them were browsing Internet for the purpose of E-mail; $31.42 \%$ of them were browsing Internet through Internet browser Mozilla Fire Fox; $37.85 \%$ of them are using Internet to update their knowledge; $82.14 \%$ of them are using Google Search engine, and $65 \%$ of them are using Gmail service for mailing purpose. The main problem faced by the students in accessing Internet is 'low speed of Internet'. 
The study made by Thanuskodi $^{\mathbf{3}}$ reveals that respondents have major problems in accessing eresources such as virus, difficulty in using digital resources due to lack of IT knowledge, and limited access to computers. The respondents sometimes have also other problems in accessing relevant information such as taking long time to view, slow accessibility, lack of time, and too much information retrieved.

Chinnasamy and Lakshmi Sankari ${ }^{4}$ studied pattern of Internet usage among the college students in Salem District. Of 27 colleges, only 8 colleges have Internet connection in their libraries for their students. The total number of students who used the Internet was around 1300 . The study considered $20 \%$ of the target population as a sample size. Thus the sample size of the current study was 260 respondents, who had used Internet for the last three months, in their respective college libraries which provide internet services to the users. The survey revealed that the majority of the respondents $(65.4 \%)$ access the Internet from cyber café. More than $57 \%$ of the respondents use the Internet services mainly for educational purpose. Search engines of Google (54.62\%) and Yahoo $(24.23 \%)$ are found to be more widely used than other search engines.

Fayaz's ${ }^{5}$ study reveals that majority of the students are frequent users of Internet using Internet from daily to weekly basis. Use of Internet by urban students is more compared to their rural counterparts. The findings further reveal that rural students mainly use Internet at home whereas urban students highly use Internet at commercial cyber cafes. Majority of the urban students use Internet primarily for specific information whereas rural students mostly use Internet for education. Majority of students, irrespective of regional differences, don't use Internet sources like emagazines, e- journals, wikis and blogs up to their expected usage. The findings also indicated that both the rural and urban students face the same problems with slight variations like information overload (too many hits) followed by Internet illiteracy (lack of Internet operating / searching skills), financial barrier, and information pollution.

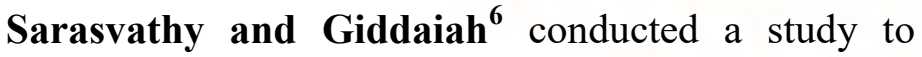
elicit opinions from the users of Internet Centre of Mysore University Library, Mysore, regarding the exploitation of Internet resources. A questionnaire tool was used to make a survey of Internet facilities at the Internet centre, Mysore University Library,
Mysore. The analysis of the data thus covers 'characteristics of study population, purposes of Internet use, mostly used Internet services, problems faced by the users while using the Internet services and suggestions made by the users for the future improvement of Internet services at Internet Centre, Mysore University Library, Mysore.

Lohar and Mallinath ${ }^{7}$ conducted a survey at Jawaharlal Nehru National College of Engineering Library, Shimoga (Karnataka) to find out the use of CD-ROMs and Internet resources and services. The study also covers the impact of these resources on the student academic work/study and also describes the problems faced by them in using the electronic resources. Hence, a survey of 110 undergraduate and post-graduate engineering students of different disciplines was conducted through questionnaire. The main intention in using CDs and Internet resources and services is due to the academic interest of the student community.

Jange and $\mathbf{S a m i}^{\mathbf{8}}$ examined the impact of Internet on libraries of National Institutes of Technology in India. As the seventeen National Institutes of Technologies are spread across the country, the questionnaire tool was found to be more feasible and was used for eliciting information from the NIT libraries. Out of 17 questionnaires sent, 10 questionnaires were received. The results shows that among the Internet services, email, online databases and WWW are the most frequently used Internet services. The librarians make use of Internet mainly for identifying latest books $(100 \%)$, and journals $(60 \%)$.

Shabani ${ }^{9}$ conducted a survey on role of the Internet in locating information by academic members in Najafabad Islamic Azad University. Survey method was used as the research method and data was collected through questionnaire tool. Collected data was analyzed by SPSS using descriptive statistics. Findings revealed that respondents used the Internet at an optimum level to update their knowledge and their research interests. In this regard, they used databanks frequently. It was found that the Internet plays a significant role for academic members to locate information so that they use it for compiling and translating books and doing research works. 


\section{NEED FOR STUDY}

Today, Internet has become an integral part of day-today activities of human life. It has not left any area untouched and library and information centers are not exception to this. The Library and Information centers play a vital role in providing right information to the right users at the right time in the right manner. Here, Internet assists library users to provide qualitative information services. Introduction and adoption of Internet is inevitable in libraries for the benefit of their users to get the required information not only from print sources but also from electronic sources. Today, the name and fame of any Institution / Library and Information Centers depends upon the sound Internet infrastructure it has. Looking into the need of the hour, the researcher has undertaken this study.

\section{OBJECTIVE OF THE STUDY}

The following are the specific objectives of the study.

1. To identify the use of Internet by different places;

2. To ascertain the experience in using Internet;

3. To ascertain the knowledge of web based services;

4. To ascertain the use of different browsers by the respondents;

5. To identify the most frequently used search engines for browsing information through Internet;

6. To ascertain the frequency of using Internet;

7. To find out the level of satisfaction with the Internet services and

8. To ascertain the problems normally encountered by using Internet

\section{HYPOTHESES}

The following hypotheses have been set up for the present investigation:

1. Most of the engineering college libraries are providing Internet facilities;
2. Majority of the engineering college library users are using the Google chrome as their web browser.

3. There is no significance difference between UG and PG with regard to the provision of Internet facility.

4. Majority of the engineering college library users are using the Google as their preferred search engine.

\section{METHODOLOGY}

There are $\mathbf{1 1 6}$ engineering colleges in Sri Venkateswara University area. The investigator selected 53 engineering college libraries out of $\mathbf{1 1 6}$ by simple random method to examine the use of Internet of these libraries. The users of engineering college libraries are undergraduate students, postgraduate students and faculty members. There are 14,706 undergraduate students, 2,722 postgraduate students and 3,433 faculty members as users of these selected 53 engineering college libraries. The total number of users in these libraries is $\mathbf{2 0 , 2 3 1}$. As the population is large in terms of the cost, time and labor involved, the investigator selected a sample of $\mathbf{1 , 3 1 4}$ users using stratified random sampling as shown below:

\begin{tabular}{|c|r|}
\hline Undergraduates & 1010 \\
\hline Post-graduates & 143 \\
\hline Faculty Members & 161 \\
\hline Total & $\mathbf{1 3 1 4}$ \\
\hline
\end{tabular}

\section{DATA ANALYSIS AND DISCUSSION RESULTS}

The data collected from the users are analysed and the results are discussed in the following paragraphs.

\subsection{Internet Facility}

A question has been put to the users whether the library possesses Internet facility. The responses given by them are shown in Table 1 .

Table 1. Distribution of users according to the to the type of library, gender, category and their responses with regard to the provision of Internet facility 
International Journal of Trend in Scientific Research and Development, Volume 1(4), ISSN: 2456-6470 www.ijtsrd.com

\begin{tabular}{|c|c|c|c|c|c|c|c|c|c|}
\hline \multirow[t]{2}{*}{ Response } & \multicolumn{3}{|c|}{ Type of library } & \multicolumn{2}{|c|}{ Gender } & \multicolumn{3}{|c|}{ Category } & \multirow[t]{2}{*}{ Total } \\
\hline & $\mathbf{U E}$ & O P E & N P E & $\mathbf{M}$ & $\mathbf{F}$ & $\mathbf{U G}$ & P G & F M & \\
\hline Yes & $\begin{array}{c}137 \\
(91.33)\end{array}$ & $\begin{array}{c}561 \\
(81.42)\end{array}$ & $\begin{array}{c}321 \\
(67.58)\end{array}$ & $\begin{array}{c}561 \\
(75.60)\end{array}$ & $\begin{array}{c}458 \\
(80.07)\end{array}$ & $\begin{array}{c}747 \\
(73.96)\end{array}$ & $\begin{array}{c}119 \\
(83.2)\end{array}$ & $\begin{array}{c}153 \\
(95.03)\end{array}$ & $\begin{array}{c}1019 \\
(77.55)\end{array}$ \\
\hline No & $\begin{array}{c}13 \\
(8.67)\end{array}$ & $\begin{array}{c}128 \\
(18.58)\end{array}$ & $\begin{array}{c}154 \\
(32.42)\end{array}$ & $\begin{array}{c}181 \\
(24.39)\end{array}$ & $\begin{array}{c}114 \\
(19.93)\end{array}$ & $\begin{array}{c}263 \\
(26.04)\end{array}$ & $\begin{array}{c}24 \\
(16.8)\end{array}$ & $\begin{array}{c}8 \\
(4.97)\end{array}$ & $\begin{array}{c}295 \\
(22.45)\end{array}$ \\
\hline Total & $\begin{array}{c}150 \\
(100.00)\end{array}$ & $\begin{array}{c}689 \\
(100.00)\end{array}$ & $\begin{array}{c}475 \\
(100.00)\end{array}$ & $\begin{array}{c}742 \\
(100.00)\end{array}$ & $\begin{array}{c}572 \\
(100.00)\end{array}$ & $\begin{array}{c}1010 \\
(100.00)\end{array}$ & $\begin{array}{c}143 \\
(100.00)\end{array}$ & $\begin{array}{c}161 \\
(100.00)\end{array}$ & $\begin{array}{c}1314 \\
(100.00)\end{array}$ \\
\hline
\end{tabular}

Note: UE: University engineering colleges, OPE: Old private engineering colleges, NPE: New private engineering colleges. Figures in parentheses indicate percentages.

\begin{tabular}{|l|l|l|l|}
\hline $\begin{array}{l}\boldsymbol{x}^{2} \text { (UG - PG) : } \\
\mathbf{3 8 . 3 7 1}\end{array}$ & df:1 & TV:3.841 & $\begin{array}{l}\text { Sig at } 0.05 \\
\text { level }\end{array}$ \\
\hline $\begin{array}{l}\boldsymbol{x}^{\mathbf{2}} \text { (UG - FM) : } \\
\mathbf{2 7 . 4 1 5}\end{array}$ & df:1 & TV:3.841 & $\begin{array}{l}\text { Sig at } 0.05 \\
\text { level }\end{array}$ \\
\hline $\begin{array}{l}\boldsymbol{x}^{\mathbf{2}} \text { (PG - FM) : } \\
\mathbf{1 8 . 6 7 4}\end{array}$ & df:1 & TV:3.841 & $\begin{array}{l}\text { Sig at } 0.05 \\
\text { level }\end{array}$ \\
\hline $\begin{array}{l}\boldsymbol{x}^{\mathbf{2}} \text { (UE - OPE): } \\
\mathbf{2 . 3 8 3}\end{array}$ & df:1 & TV:3.841 & $\begin{array}{l}\text { N Sig at } \\
0.05 \text { level }\end{array}$ \\
\hline $\begin{array}{l}\boldsymbol{x}^{\mathbf{2}} \text { (UE - NPE): } \\
\mathbf{6 . 1 4 3}\end{array}$ & df:1 & TV:3.841 & $\begin{array}{l}\text { Sig at } 0.05 \\
\text { level }\end{array}$ \\
\hline $\begin{array}{l}\boldsymbol{x}^{\mathbf{2}}(\mathbf{O P E}- \\
\text { NPE) } \mathbf{1 6 . 4 3 2}\end{array}$ & df:1 & TV:3.841 & $\begin{array}{l}\text { Sig at } 0.05 \\
\text { level }\end{array}$ \\
\hline $\begin{array}{l}\boldsymbol{x}^{\mathbf{2}}(\mathbf{M}-\mathbf{F}): \\
\mathbf{9 . 5 4 3}\end{array}$ & df:1 & TV:3.841 & $\begin{array}{l}\text { Sig at } 0.05 \\
\text { level }\end{array}$ \\
\hline
\end{tabular}

Table 1 shows, majority of the users (77.55\%) replied that their libraries are providing Internet facility and the remaining 22.45 per cent replied negatively.

It is obvious from the table that there is a significant difference in their replies with regard to the provision of Internet facility in their libraries concerned between the users of undergraduates and postgraduates on one hand and undergraduates and faculty members on the other hand. It is indicated by the Chi-square values which are significant at 0.05 level with one degree of freedom, which means more number of faculty members and postgraduates replied that their libraries are providing Internet facility compared to undergraduates.

It is also obvious from the table that there is a significant difference in their replies with regard to the provision of Internet facility between the users of postgraduates and faculty members. It is indicated by the Chi-square values which are significant at 0.05 level with one degree of freedom. This means more

number of faculty members replied that their libraries are providing Internet facility compared to postgraduates.

It is also evident from the table that there is no significant difference in the replies with regard to the provision of Internet facility between the users of University engineering college libraries and old Private engineering college libraries. It is indicated by the Chi-square value which is not significant at 0.05 level with one degree of freedom.

It can also be seen from the table that there is a significant difference in provision of Internet facility among the users of University engineering college libraries and new Private engineering college libraries on one hand, and old Private engineering college libraries and new Private engineering college libraries on the other hand. It is indicated by the Chi-square values which are significant at 0.05 level with one degree of freedom, which means more number of users of University engineering college libraries and old private engineering college libraries replied their libraries are providing Internet facility compared to the users of new Private engineering college libraries.

It is also noticed that there is a significant difference between men and women users with regard to the provision of Internet facility. It is provided by the Chi-square values which are significant at 0.05 level with one degree of freedom, which means more number of women users replied that their libraries are providing Internet facility compared to the men users.

Hypothesis number one states that "Most of the engineering college libraries are provid - ing Internet facilities". This was verified from the data collected and it is found to be true (vide Table 1). 
Hypothesis number three states that "There is no significance difference between UG and PG with regard to the provision of Internet facility". This was verified from the data collected and it is found to be true (vide Table 1).

\subsection{Place of using Internet}

A question has been put to the users to know the most frequently used place of Internet. The responses given by them are shown in Table 2 and diagrammatically in Fig 1.

\begin{tabular}{|c|c|c|c|c|c|c|c|c|c|}
\hline \multirow[b]{2}{*}{ Place } & \multicolumn{3}{|c|}{ Type of library } & \multicolumn{2}{|c|}{ Gender } & \multicolumn{3}{|c|}{ Category } & \multirow{2}{*}{$\begin{array}{c}\text { Total } \\
\mathbf{N}=1314\end{array}$} \\
\hline & $\begin{array}{c}\mathbf{U} \mathbf{E} \\
\mathbf{n}=\mathbf{1 5 0}\end{array}$ & $\begin{array}{l}\text { O P E } \\
n=689\end{array}$ & $\begin{array}{l}\text { N P E } \\
n=475\end{array}$ & $\underset{n=742}{M}$ & $\begin{array}{c}\mathrm{F} \\
\mathrm{n}=572\end{array}$ & $\underset{\mathbf{n}=1010}{\mathbf{U} \mathbf{G}}$ & $\underset{n=143}{P G}$ & $\begin{array}{c}F M \\
\mathbf{n}=161\end{array}$ & \\
\hline Computer lab & $\begin{array}{c}32 \\
(21.33)\end{array}$ & $\begin{array}{c}196 \\
(28.44)\end{array}$ & $\begin{array}{c}161 \\
(33.89)\end{array}$ & $\begin{array}{c}248 \\
(44.20)\end{array}$ & $\begin{array}{c}141 \\
(30.78)\end{array}$ & $\begin{array}{c}294 \\
(29.10)\end{array}$ & $\begin{array}{c}31 \\
(21.67)\end{array}$ & $\begin{array}{c}64 \\
(39.75)\end{array}$ & $\begin{array}{c}389 \\
(29.60)\end{array}$ \\
\hline Library & $\begin{array}{c}63 \\
(42)\end{array}$ & $\begin{array}{c}307 \\
(44.55)\end{array}$ & $\begin{array}{c}157 \\
(33.05)\end{array}$ & $\begin{array}{c}280 \\
(49.91)\end{array}$ & $\begin{array}{c}247 \\
(53.93)\end{array}$ & $\begin{array}{c}388 \\
(38.41)\end{array}$ & $\begin{array}{c}68 \\
(47.55) \\
\end{array}$ & $\begin{array}{c}71 \\
(44.09)\end{array}$ & $\begin{array}{c}527 \\
(40.11)\end{array}$ \\
\hline At department & $\begin{array}{c}22 \\
(14.66)\end{array}$ & $\begin{array}{c}101 \\
(14.65)\end{array}$ & $\begin{array}{c}48 \\
(10.1)\end{array}$ & $\begin{array}{c}98 \\
(17.46)\end{array}$ & $\begin{array}{c}73 \\
(15.93)\end{array}$ & $\begin{array}{c}128 \\
(12.67)\end{array}$ & $\begin{array}{c}13 \\
(9.09)\end{array}$ & $\begin{array}{c}30 \\
(18.63)\end{array}$ & $\begin{array}{c}171 \\
(13.01)\end{array}$ \\
\hline At home & $\begin{array}{c}60 \\
(40)\end{array}$ & $\begin{array}{c}233 \\
(33.18)\end{array}$ & $\begin{array}{c}139 \\
(26.26)\end{array}$ & $\begin{array}{c}262 \\
(46.70)\end{array}$ & $\begin{array}{c}170 \\
(37.11)\end{array}$ & $\begin{array}{c}323 \\
(31.98)\end{array}$ & $\begin{array}{c}47 \\
(32.86)\end{array}$ & $\begin{array}{c}62 \\
(38.50)\end{array}$ & $\begin{array}{c}432 \\
(32.88)\end{array}$ \\
\hline $\begin{array}{l}\text { At Internet } \\
\text { café }\end{array}$ & $\begin{array}{c}36 \\
(24)\end{array}$ & $\begin{array}{c}130 \\
(18.86)\end{array}$ & $\begin{array}{c}90 \\
(18.94)\end{array}$ & $\begin{array}{c}164 \\
(29.23)\end{array}$ & $\begin{array}{c}92 \\
(20.08)\end{array}$ & $\begin{array}{c}192 \\
(19.00)\end{array}$ & $\begin{array}{c}27 \\
(18.88)\end{array}$ & $\begin{array}{c}37 \\
(22.98)\end{array}$ & $\begin{array}{c}256 \\
(19.48)\end{array}$ \\
\hline
\end{tabular}

Table 2 Distribution of users according to the to the type of library, gender, category and their responses with regard to the most frequently used place of Internet

Note: Figures in parenthesis indicate percentages. Users are permitted to tick more than one answer.

It is evident from Table 2 that a high percentage of 29.60 per cent of them at computer lab, 19.48 per cent users $(40.11 \%)$ use Internet most frequently at their of them at Internet cafe and the remaining 13.01 per respective libraries, 32.88 per cent of them at home, cent of them at department.

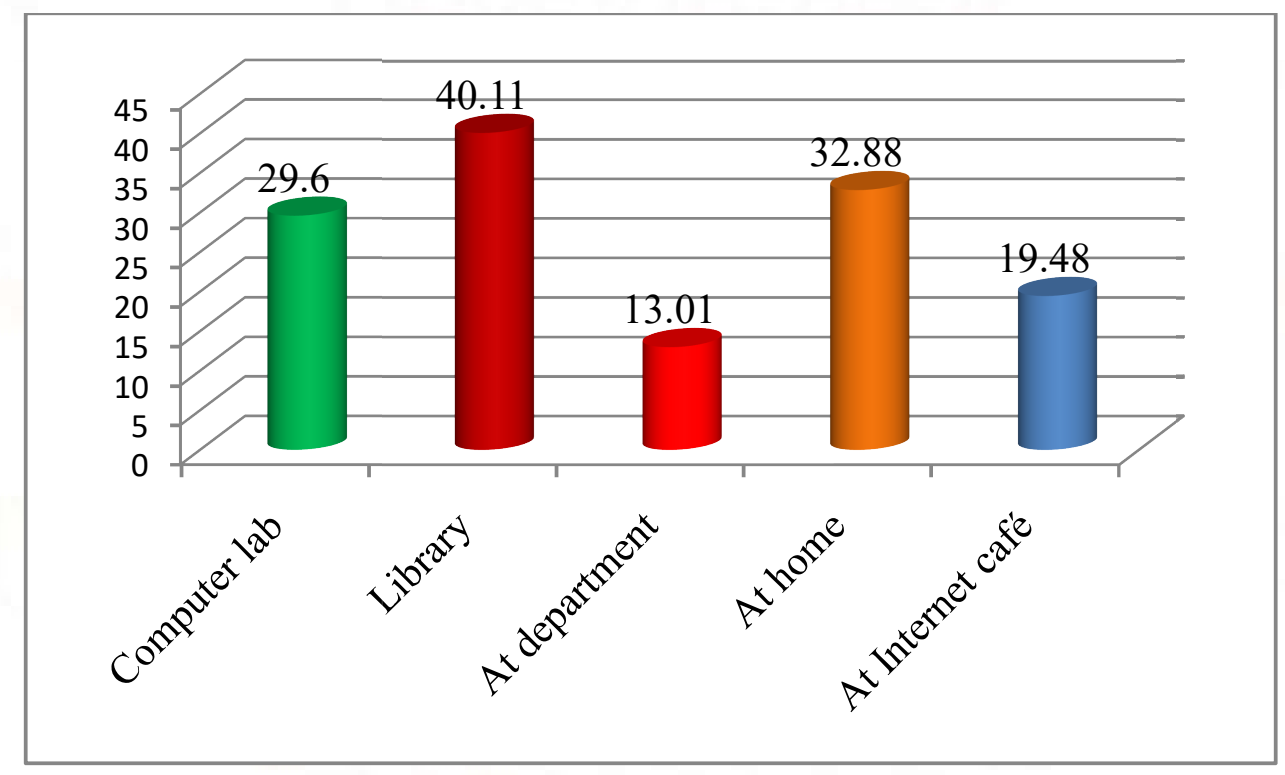

Figure : 1 Distribution of users according to the to the type of library, gender, category and their responses with regard to the most frequently used place of Internet 
International Journal of Trend in Scientific Research and Development, Volume 1(4), ISSN: 2456-6470 www.ijtsrd.com

\subsection{Frequency of using of Internet}

A question has been put to the users to know the frequency of using Internet. The responses given by them are shown in Table 3

\begin{tabular}{|c|c|c|c|c|c|c|c|c|c|}
\hline \multirow{2}{*}{ Frequency } & \multicolumn{3}{|c|}{ Type of library } & \multicolumn{2}{|c|}{ Gender } & \multicolumn{3}{|c|}{ Category } & \multirow[t]{2}{*}{ Total } \\
\hline & $\mathbf{U} \mathbf{E}$ & O P E & N P E & $\overline{\mathbf{M}}$ & $\mathbf{F}$ & $\mathbf{U} \mathbf{G}$ & P G & F M & \\
\hline Eve & $\begin{array}{c}50 \\
(33.33)\end{array}$ & $\begin{array}{c}242 \\
(35.12)\end{array}$ & $\begin{array}{c}133 \\
(28.00)\end{array}$ & $\begin{array}{c}294 \\
(39.62)\end{array}$ & $\begin{array}{c}131 \\
(22.90)\end{array}$ & $\begin{array}{c}290 \\
(28.71)\end{array}$ & $\begin{array}{c}47 \\
(32.86)\end{array}$ & $\begin{array}{c}88 \\
(34.67)\end{array}$ & $\begin{array}{c}425 \\
(32.34)\end{array}$ \\
\hline $\begin{array}{l}2 \text { to } \\
\text { in a }\end{array}$ & $\begin{array}{c}50 \\
(33.33)\end{array}$ & $\begin{array}{c}247 \\
(35.85)\end{array}$ & $\begin{array}{c}188 \\
(39.58)\end{array}$ & $\begin{array}{c}230 \\
(30.99)\end{array}$ & $\begin{array}{c}255 \\
(44.59)\end{array}$ & $\begin{array}{c}378 \\
(37.42)\end{array}$ & $\begin{array}{c}51 \\
(35.67)\end{array}$ & $\begin{array}{c}56 \\
(34.78)\end{array}$ & $\begin{array}{c}485 \\
(36.91)\end{array}$ \\
\hline $\begin{array}{l}2 \text { to } 3 \\
\text { in a }\end{array}$ & $\begin{array}{c}18 \\
(12.00)\end{array}$ & $\begin{array}{c}72 \\
(10.45)\end{array}$ & $\begin{array}{c}43 \\
(9.05)\end{array}$ & $\begin{array}{c}67 \\
(9.05)\end{array}$ & $\begin{array}{c}66 \\
(4.54)\end{array}$ & $\begin{array}{c}115 \\
(4.39)\end{array}$ & $\begin{array}{c}14 \\
(9.79)\end{array}$ & $\begin{array}{c}4 \\
(2.48)\end{array}$ & $\begin{array}{c}133 \\
(10.12)\end{array}$ \\
\hline $\begin{array}{l}\text { Once in a } \\
\text { month }\end{array}$ & $\begin{array}{c}8 \\
(5.34)\end{array}$ & $\begin{array}{c}45 \\
(6.53)\end{array}$ & $\begin{array}{c}36 \\
(7.58)\end{array}$ & $\begin{array}{c}58 \\
(7.81)\end{array}$ & $\begin{array}{c}31 \\
(5.42)\end{array}$ & $\begin{array}{c}80 \\
(7.92)\end{array}$ & $\begin{array}{c}9 \\
(6.29)\end{array}$ & 0 & $\begin{array}{c}89 \\
(6.77)\end{array}$ \\
\hline Occasionally & $\begin{array}{c}24 \\
(16.00)\end{array}$ & $\begin{array}{c}83 \\
(12.05)\end{array}$ & $\begin{array}{c}75 \\
(15.79)\end{array}$ & $\begin{array}{c}93 \\
(12.53)\end{array}$ & $\begin{array}{c}89 \\
(15.55)\end{array}$ & $\begin{array}{c}147 \\
(14.56)\end{array}$ & $\begin{array}{c}22 \\
(15.39)\end{array}$ & $\begin{array}{c}13 \\
(8.07)\end{array}$ & $\begin{array}{c}182 \\
(13.85)\end{array}$ \\
\hline Total & $\begin{array}{c}150 \\
(100.00)\end{array}$ & $\begin{array}{c}689 \\
(100.00)\end{array}$ & $\begin{array}{c}475 \\
(100.00)\end{array}$ & $\begin{array}{c}742 \\
(100.00)\end{array}$ & $\begin{array}{c}572 \\
(100.00)\end{array}$ & $\begin{array}{c}1010 \\
(100.00)\end{array}$ & $\begin{array}{c}143 \\
(100.00)\end{array}$ & $\begin{array}{c}161 \\
(100.00)\end{array}$ & $\begin{array}{c}1314 \\
(100.00)\end{array}$ \\
\hline
\end{tabular}

Note: Figures in parenthesis indicate percentages

It is evident from Table 3 that over a third of users (36.91\%) replied that they are using Internet 2 to 3 times in a week, 32.34 per cent are using every day, 13.85 per cent are using occasionally, 10.12 per cent are using 2 to 3 times in a month and the remaining 6.77 per cent are using Internet once in a month.

\subsection{Experience in using Internet}

A question has been put to the users to know their experience in using Internet. The responses given by them are shown in Table 4.

\begin{tabular}{|c|c|c|c|c|c|c|c|c|c|}
\hline \multirow[t]{2}{*}{ Experience } & \multicolumn{3}{|c|}{ Type of library } & \multicolumn{2}{|c|}{ Gender } & \multicolumn{3}{|c|}{ Category } & \multirow[t]{2}{*}{ Total } \\
\hline & $\mathbf{U} \mathbf{E}$ & O P E & N P E & M & $\mathbf{F}$ & $\mathbf{U} \mathbf{G}$ & P G & F M & \\
\hline $\begin{array}{l}\text { Less } \\
\text { one }\end{array}$ & $\begin{array}{c}24 \\
(16.00)\end{array}$ & $\begin{array}{c}106 \\
(15.39)\end{array}$ & $\begin{array}{c}58 \\
(12.21)\end{array}$ & $\begin{array}{c}93 \\
(12.53)\end{array}$ & $\begin{array}{c}95 \\
(16.61)\end{array}$ & $\begin{array}{c}151 \\
(14.95)\end{array}$ & $\begin{array}{c}31 \\
(21.68)\end{array}$ & $\begin{array}{c}6 \\
(3.73)\end{array}$ & $\begin{array}{c}188 \\
(14.31)\end{array}$ \\
\hline 1-2 Years & $\begin{array}{c}62 \\
(41.34)\end{array}$ & $\begin{array}{c}259 \\
(37.59)\end{array}$ & $\begin{array}{c}227 \\
(47.79)\end{array}$ & $\begin{array}{c}272 \\
(36.65)\end{array}$ & $\begin{array}{c}276 \\
(48.25)\end{array}$ & $\begin{array}{c}478 \\
(47.33)\end{array}$ & $\begin{array}{c}58 \\
(40.56)\end{array}$ & $\begin{array}{c}12 \\
(7.45)\end{array}$ & $\begin{array}{c}548 \\
(41.70)\end{array}$ \\
\hline 2-4 Years & $\begin{array}{c}26 \\
(17.33)\end{array}$ & $\begin{array}{c}113 \\
(16.40)\end{array}$ & $\begin{array}{c}89 \\
(18.74)\end{array}$ & $\begin{array}{c}126 \\
(16.99)\end{array}$ & $\begin{array}{c}102 \\
(17.83)\end{array}$ & $\begin{array}{c}192 \\
(19.01)\end{array}$ & $\begin{array}{c}26 \\
(18.18)\end{array}$ & $\begin{array}{c}10 \\
(6.21)\end{array}$ & $\begin{array}{c}228 \\
(17.35)\end{array}$ \\
\hline $\begin{array}{l}\text { More than } \\
4 \text { years }\end{array}$ & $\begin{array}{c}38 \\
(25.33)\end{array}$ & $\begin{array}{c}211 \\
(30.62)\end{array}$ & $\begin{array}{c}101 \\
(21.26)\end{array}$ & $\begin{array}{c}251 \\
(33.83)\end{array}$ & $\begin{array}{c}99 \\
(17.31)\end{array}$ & $\begin{array}{c}189 \\
(18.71)\end{array}$ & $\begin{array}{c}28 \\
(19.58)\end{array}$ & $\begin{array}{c}133 \\
(82.61)\end{array}$ & $\begin{array}{c}350 \\
(26.64)\end{array}$ \\
\hline Total & $\begin{array}{c}150 \\
(100.00)\end{array}$ & $\begin{array}{c}689 \\
(100.00)\end{array}$ & $\begin{array}{c}475 \\
(100.00)\end{array}$ & $\begin{array}{c}742 \\
(100.00)\end{array}$ & $\begin{array}{c}572 \\
(43.53)\end{array}$ & $\begin{array}{c}1010 \\
(100.00)\end{array}$ & $\begin{array}{c}143 \\
(100.00)\end{array}$ & $\begin{array}{c}161 \\
(100.00)\end{array}$ & $\begin{array}{c}1314 \\
(100.00)\end{array}$ \\
\hline
\end{tabular}


Table 4 Distribution of users according to the to the type of library, gender, category and their responses with regard to the experience in Internet use

Note: Figures in parenthesis indicate percentages

\begin{tabular}{|c|c|c|c|}
\hline $\begin{array}{l}x^{2}(\mathrm{UG}-\mathrm{PG}): \\
8.539\end{array}$ & $\mathrm{df}: 3$ & TV:7.815 & $\begin{array}{l}\text { Sig at } 0.05 \\
\text { level }\end{array}$ \\
\hline $\begin{array}{l}x^{2}(\mathrm{UG}-\mathrm{FM}): \\
1.433\end{array}$ & $\mathrm{df}: 3$ & TV:7.815 & $\begin{array}{l}\text { N Sig at } \\
0.05 \text { level }\end{array}$ \\
\hline $\begin{array}{l}x^{2}(\mathrm{PG}-\mathrm{FM}): \\
1.382\end{array}$ & $\mathrm{df}: 3$ & TV:7.815 & $\begin{array}{l}\text { N Sig at } \\
0.05 \text { level }\end{array}$ \\
\hline $\begin{array}{l}x^{2}(\mathrm{UE} \\
-\mathrm{OPE}): 8.415\end{array}$ & $\mathrm{df}: 3$ & TV:7.815 & $\begin{array}{l}\text { Sig at } 0.05 \\
\text { level }\end{array}$ \\
\hline $\begin{array}{l}\mathrm{x}^{2}(\mathrm{UE} \\
-\mathrm{NPE}): 6.753\end{array}$ & $\mathrm{df}: 3$ & TV:7.815 & $\begin{array}{l}\text { N Sig at } \\
0.05 \text { level }\end{array}$ \\
\hline $\begin{array}{l}\mathrm{x}^{2} \text { (OPE } \\
-\mathrm{NPE}): 7.834\end{array}$ & $\mathrm{df}: 3$ & TV:7.815 & $\begin{array}{l}\text { Sig at } 0.05 \\
\text { level }\end{array}$ \\
\hline $\mathrm{x}^{2}(\mathrm{M}-\mathrm{F}): 9.874$ & $\mathrm{df}: 3$ & TV:7.815 & $\begin{array}{l}\text { Sig at } 0.05 \\
\text { level }\end{array}$ \\
\hline
\end{tabular}

It can also be seen from the table that there is a significant difference in the experience of using Internet use among the users of University engineering college libraries and old Private engineering college libraries on one hand, and old private engineering college libraries and new Private engineering college libraries on the other hand. It is indicated by the Chi-square values which are significant at 0.05 level with three degrees of freedom, which means the users of old Private engineering college libraries are having more experience in using Internet compared to users of new Private engineering college libraries, and University engineering college libraries. However, there is no significant difference in the experience of using Internet between the users of University engineering college libraries and new Private engineering college libraries. It is indicated by the Chi-square value which is not significant at 0.05 level with three degrees of freedom.

users $(41.70 \%)$ replied that they have been using the Internet from 1-2 Years. Another 26.64 per cent of users have been using Internet for more than 4 years, 17.35 per cent of them have been using it from 2-4 Years and the remaining 14.31 per cent of them have been using it from less than one year.

It is obvious from Table 4 that there is a significant difference in the experience of using Internet between the users of undergraduates and postgraduates. It is proved by the Chi-square value which is significant at 0.05 level with three degrees of freedom.

It is also obvious from table that there is no significant difference in the experience of using Internet between the users of undergraduates and faculty members on one hand, and postgraduates and faculty members on the other hand. It is proved by the Chi-square values which are significant at 0.05 level with three degrees of freedom.

It is also noticed that there is a significant difference between men and women users in the experience of using Internet. It is provided by the Chi-square value which is significant at 0.05 level with three degrees of freedom, which means men users have more experience in using Internet compared to the women users.

\subsection{Types of Internet browsers used}

An Internet browser is the programme through which one can access the Internet and view web pages. A question has been put to the users to know the type of Internet browser used. The responses given by them are shown in Table 5 and diagrammatically in Fig 2

\begin{tabular}{|c|c|c|c|c|c|c|c|c|c|}
\hline \multirow[b]{2}{*}{$\begin{array}{l}\text { Internet } \\
\text { browsers }\end{array}$} & \multicolumn{3}{|c|}{ Type of library } & \multicolumn{2}{|c|}{ Gender } & \multicolumn{3}{|c|}{ Category } & \multirow{2}{*}{$\begin{array}{c}\text { Total } \\
\mathbf{N}=1314\end{array}$} \\
\hline & $\begin{array}{c}\mathbf{U E} \\
\mathbf{n}=\mathbf{1 5 0}\end{array}$ & $\begin{array}{l}\text { O P E } \\
n=689\end{array}$ & $\begin{array}{l}\text { N P E } \\
n=475\end{array}$ & $\begin{array}{c}\text { M } \\
n=742\end{array}$ & $\begin{array}{c}\mathbf{F} \\
\mathbf{n}=\mathbf{5 7 2}\end{array}$ & $\begin{array}{c}\text { UG } \\
n=1010\end{array}$ & $\begin{array}{c}\text { P G } \\
n=143\end{array}$ & $\begin{array}{c}\text { F M } \\
n=161\end{array}$ & \\
\hline $\begin{array}{l}\text { Mozilla } \\
\text { Firefox }\end{array}$ & $\begin{array}{c}92 \\
61.33)\end{array}$ & $\begin{array}{c}443 \\
(64.29)\end{array}$ & $\begin{array}{c}312 \\
(68.68)\end{array}$ & $\begin{array}{c}506 \\
(68.19)\end{array}$ & $\begin{array}{c}341 \\
(59.61)\end{array}$ & $\begin{array}{c}660 \\
(65.34)\end{array}$ & $\begin{array}{c}87 \\
(60.83)\end{array}$ & $\begin{array}{c}100 \\
(62.11)\end{array}$ & $\begin{array}{c}847 \\
(64.46)\end{array}$ \\
\hline $\begin{array}{l}\text { Internet } \\
\text { explorer }\end{array}$ & $\begin{array}{c}92 \\
(61.33)\end{array}$ & $\begin{array}{c}421 \\
(61.1)\end{array}$ & $\begin{array}{c}278 \\
(58.52)\end{array}$ & $\begin{array}{c}394 \\
(53.09)\end{array}$ & $\begin{array}{c}397 \\
(69.4)\end{array}$ & $\begin{array}{c}600 \\
(59.40)\end{array}$ & $\begin{array}{c}87 \\
(60.83)\end{array}$ & $\begin{array}{c}104 \\
(64.59)\end{array}$ & $\begin{array}{c}791 \\
(60.20)\end{array}$ \\
\hline
\end{tabular}


International Journal of Trend in Scientific Research and Development, Volume 1(4), ISSN: 2456-6470 www.ijtsrd.com

\begin{tabular}{|l|c|c|c|c|c|c|c|c|c|}
\hline $\begin{array}{l}\text { Google } \\
\text { chrome }\end{array}$ & $\begin{array}{c}89 \\
(59.33)\end{array}$ & $\begin{array}{c}444 \\
(64.44)\end{array}$ & $\begin{array}{c}315 \\
(66.31)\end{array}$ & $\begin{array}{c}457 \\
(61.59)\end{array}$ & $\begin{array}{c}391 \\
(68.35)\end{array}$ & $\begin{array}{c}656 \\
(6.43)\end{array}$ & $\begin{array}{c}98 \\
(68.53)\end{array}$ & $\begin{array}{c}94 \\
(58.38)\end{array}$ & $\begin{array}{c}848 \\
(64.54)\end{array}$ \\
\hline Safari & 4 & 17 & 23 & 33 & 11 & 43 & 1 & 0 & 44 \\
& $(2.66)$ & $(2.46)$ & $(4.84)$ & $(4.44)$ & $(1.92)$ & $(42.87)$ & $(0.69)$ & & $(3.35)$ \\
\hline Opera & 18 & 104 & 51 & 127 & 46 & 132 & 18 & 23 & 173 \\
& $(12)$ & $(15.09)$ & $(1073)$ & $(17.11)$ & $(8.04)$ & $(13.06)$ & $(12.58)$ & $(14.28)$ & $(13.17)$ \\
\hline Neo planet & 1 & 10 & 5 & 10 & 6 & 14 & 2 & 0 & 16 \\
& $(0.66)$ & $(1.45)$ & $(1.05)$ & $(13.47)$ & $(1.04)$ & $(1.38)$ & $(1.39)$ & & $(1.22)$ \\
\hline Others & 1 & 3 & 5 & 9 & 0 & 8 & 1 & 0 & 9 \\
& $(0.66)$ & $(0.43)$ & $(1.05)$ & $(1.21)$ & & $(0.79)$ & $(0.69)$ & & $(0.68)$ \\
\hline
\end{tabular}

Table 5 Distribution of users according to the type of library, gender, category and their responses with regard to the type of Internet browsers used

Note: Figures in parenthesis indicate percentages. Users are permitted to tick more than one answer

It is evident from Table 5 that majority of the users (65.54\%) are using the Google chrome as an Internet browser. It is also evident from the table that majority of them are also using Mozilla Firefox $(64.46 \%)$, and Internet explorer (60.20\%). The table shows that 13.17 per cent of them are using opera; 3.35 per cent of them are using Safari; and 1.22 per cent of them are using Neo planet; and the remaining 0.68 per cent of them are using other browsers.

Hypothesis number two states that "Majority of the engineering college library users are using the Google chrome as their web browser." This was verified from the data collected and it is found to be true (vide Table 5).

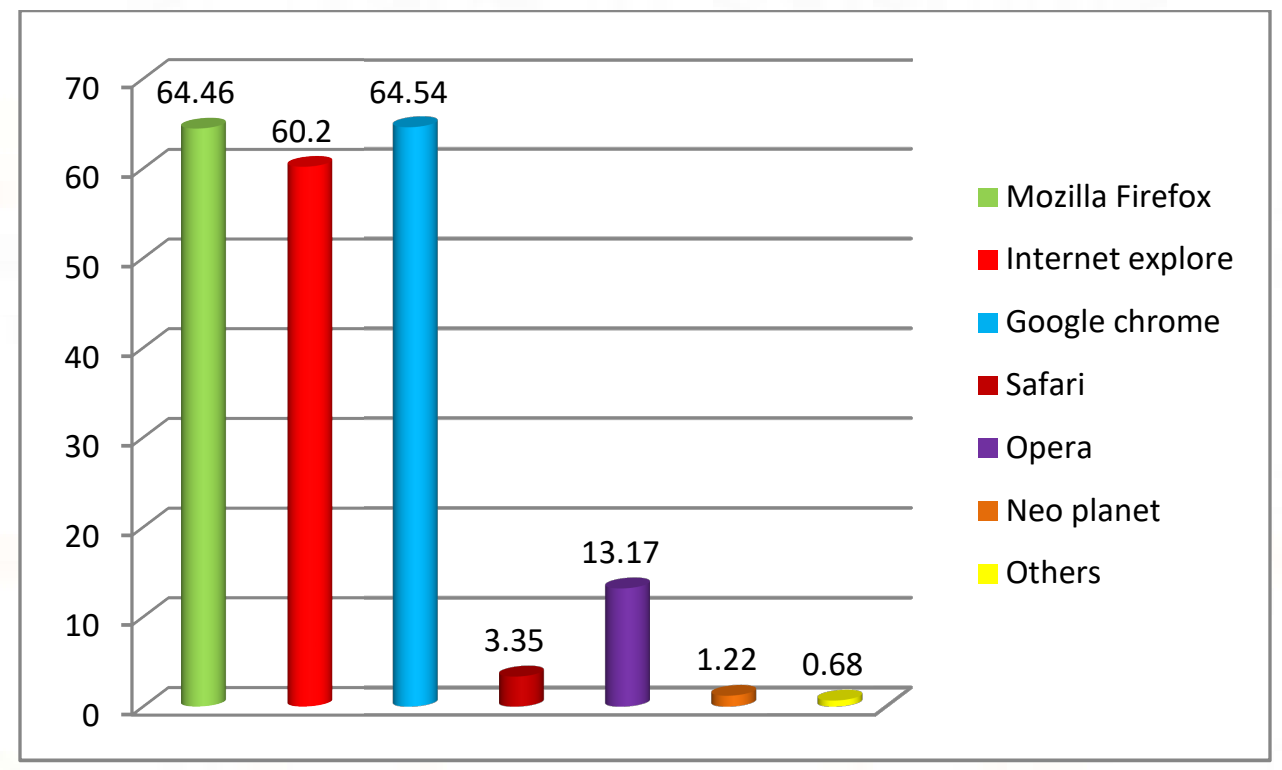

Figure: 2 Distribution of users according to the type of library, gender, category and their responses with regard to the type of Internet browsers used

\subsection{Preferred search engines}

Search engine is a programme that allows users to locate specified information from the World Wide
Web. A question has been put to the users to know their preferred search engines. The responses given by them are shown in Table 6 
International Journal of Trend in Scientific Research and Development, Volume 1(4), ISSN: 2456-6470 www.ijtsrd.com

\begin{tabular}{|c|c|c|c|c|c|c|c|c|c|}
\hline \multirow{2}{*}{$\begin{array}{l}\text { Preferre } \\
\text { d search } \\
\text { engines }\end{array}$} & \multicolumn{3}{|c|}{ Type of library } & \multicolumn{2}{|c|}{ Gender } & \multicolumn{3}{|c|}{ Category } & \multirow[b]{2}{*}{$\begin{array}{c}\text { Total } \\
\mathbf{N}=131 \\
4 \\
\end{array}$} \\
\hline & $\begin{array}{c}\mathbf{U E} \\
n=150\end{array}$ & $\begin{array}{l}\text { O P E } \\
n=689\end{array}$ & $\begin{array}{l}\text { N P E } \\
n=475\end{array}$ & $\begin{array}{c}M \\
n=742\end{array}$ & $\begin{array}{c}F \\
n=572\end{array}$ & $\begin{array}{c}\text { U G } \\
n=1010\end{array}$ & $\begin{array}{c}\text { P G } \\
n=143\end{array}$ & $\begin{array}{c}\text { F M } \\
n=161\end{array}$ & \\
\hline $\begin{array}{l}\text { Alta } \\
\text { Vista }\end{array}$ & $\begin{array}{c}6 \\
(4)\end{array}$ & $\begin{array}{c}67 \\
(9.72)\end{array}$ & $\begin{array}{c}15 \\
(8.57)\end{array}$ & $\begin{array}{c}38 \\
(5.12)\end{array}$ & $\begin{array}{c}50 \\
(8.74)\end{array}$ & $\begin{array}{c}44 \\
(4.35)\end{array}$ & $\begin{array}{c}13 \\
(9.09)\end{array}$ & $\begin{array}{c}31 \\
(19.25)\end{array}$ & $\begin{array}{c}88 \\
(6.70)\end{array}$ \\
\hline Google & $\begin{array}{c}139 \\
(92.66)\end{array}$ & $\begin{array}{c}628 \\
(91.14)\end{array}$ & $\begin{array}{c}449 \\
(94.52)\end{array}$ & $\begin{array}{c}691 \\
(93.12)\end{array}$ & $\begin{array}{c}525 \\
(91.78)\end{array}$ & $\begin{array}{c}939 \\
(92.97)\end{array}$ & $\begin{array}{c}126 \\
(88.11)\end{array}$ & $\begin{array}{c}151 \\
(93.78)\end{array}$ & $\begin{array}{c}1216 \\
(92.54)\end{array}$ \\
\hline Lycos & $\begin{array}{c}2 \\
(1.33) \\
\end{array}$ & $\begin{array}{c}60 \\
(8.70) \\
\end{array}$ & $\begin{array}{c}12 \\
(6.85) \\
\end{array}$ & $\begin{array}{c}49 \\
(60.60) \\
\end{array}$ & $\begin{array}{c}25 \\
(4.37) \\
\end{array}$ & $\begin{array}{c}28 \\
(2.77) \\
\end{array}$ & $\begin{array}{c}5 \\
(3.49) \\
\end{array}$ & $\begin{array}{c}41 \\
(25.46) \\
\end{array}$ & $\begin{array}{c}74 \\
(5.63) \\
\end{array}$ \\
\hline $\begin{array}{l}\text { MSN } \\
\text { search }\end{array}$ & $\begin{array}{c}16 \\
(10.66)\end{array}$ & $\begin{array}{c}69 \\
(10.01)\end{array}$ & $\begin{array}{c}56 \\
(32)\end{array}$ & $\begin{array}{c}94 \\
(12.66)\end{array}$ & $\begin{array}{c}47 \\
(8.21)\end{array}$ & $\begin{array}{c}104 \\
(10.29)\end{array}$ & $\begin{array}{c}21 \\
(14.68)\end{array}$ & $\begin{array}{c}16 \\
(9.93)\end{array}$ & $\begin{array}{c}141 \\
(10.73)\end{array}$ \\
\hline Yahoo & $\begin{array}{c}43 \\
(28.66) \\
\end{array}$ & $\begin{array}{c}226 \\
(32.80) \\
\end{array}$ & $\begin{array}{c}167 \\
(95.42) \\
\end{array}$ & $\begin{array}{c}254 \\
(34.23) \\
\end{array}$ & $\begin{array}{c}182 \\
(31.8) \\
\end{array}$ & $\begin{array}{c}350 \\
(34.65) \\
\end{array}$ & $\begin{array}{c}49 \\
(34.26) \\
\end{array}$ & $\begin{array}{c}37 \\
(22.98) \\
\end{array}$ & $\begin{array}{c}436 \\
(33.18) \\
\end{array}$ \\
\hline Hot boot & $\begin{array}{c}3 \\
(2) \\
\end{array}$ & $\begin{array}{c}22 \\
(3.19) \\
\end{array}$ & $\begin{array}{c}10 \\
(5.71) \\
\end{array}$ & $\begin{array}{c}19 \\
(2.56) \\
\end{array}$ & $\begin{array}{c}16 \\
(2.79) \\
\end{array}$ & $\begin{array}{c}24 \\
(2.37) \\
\end{array}$ & $\begin{array}{c}4 \\
(2.79) \\
\end{array}$ & $\begin{array}{c}7 \\
(4.34) \\
\end{array}$ & $\begin{array}{c}35 \\
(2.66) \\
\end{array}$ \\
\hline Exite & $\begin{array}{c}2 \\
(1.33) \\
\end{array}$ & $\begin{array}{c}11 \\
(1.59)\end{array}$ & $\begin{array}{c}15 \\
(8.57)\end{array}$ & $\begin{array}{c}17 \\
(2.29)\end{array}$ & $\begin{array}{c}11 \\
(1.92)\end{array}$ & $\begin{array}{c}28 \\
(2.77) \\
\end{array}$ & 0 & 0 & $\begin{array}{c}28 \\
(2.13)\end{array}$ \\
\hline Others & 0 & $\begin{array}{c}2 \\
(0.29)\end{array}$ & $\begin{array}{c}4 \\
(2.28)\end{array}$ & 0 & $\begin{array}{c}6 \\
(1.04)\end{array}$ & $\begin{array}{c}4 \\
(0.39)\end{array}$ & $\begin{array}{c}2 \\
(1.3 .9)\end{array}$ & 0 & $\begin{array}{c}6 \\
(0.46)\end{array}$ \\
\hline
\end{tabular}

Table 6 Distribution of users according to the type of library, gender, category and their responses with regard to their preferred search engines

Note: Figures in parenthesis indicate percentage. Users are permitted to tick more than one answer

Table 6 shows, most of the users (92.54\%) replied that Google is the preferred search engine. It is also evident from the table that 33.18 per cent of them are preferring Yahoo, 10.73 per cent of them are preferring MSN Search, 6.70 per cent of them are preferring Alta Vista, 5.63 per cent of them are preferring Lycos, 2.66 per cent of them are preferring Hot boot, 2.13 per cent of them are preferring Exite and the remaining 0.46 per cent of them are preferring others.
Hypothesis number Four states that "Majority of the engineering college library users are using the Google as their preferred search engine". This was verified from the data collected and it is found to be true (vide Table 6).

\subsection{Use of Internet services}

A question has been put to the users to know the various Internet services regularly used by them. The responses given by them are shown in Table 7 .

\begin{tabular}{|c|c|c|c|c|c|c|c|c|c|}
\hline \multirow{2}{*}{$\begin{array}{l}\text { Internet } \\
\text { services }\end{array}$} & \multicolumn{3}{|c|}{ Type of library } & \multicolumn{2}{|c|}{ Gender } & \multicolumn{3}{|c|}{ Category } & \multirow{2}{*}{$\begin{array}{c}\text { Total } \\
\mathbf{N}=1314\end{array}$} \\
\hline & $\underset{\mathbf{n}=150}{\mathbf{U} \mathbf{E}}$ & & $\begin{array}{l}\mathbf{N} \mathbf{~} \\
\mathbf{n}=4\end{array}$ & $\underset{n=742}{M}$ & $\begin{array}{c}\mathbf{F} \\
\mathrm{n}=572\end{array}$ & $\underset{\mathbf{n}=1010}{\mathbf{U} \mathbf{G}}$ & $\underset{\mathbf{n}=\mathbf{1 4 3}}{\mathbf{P G}}$ & & \\
\hline & $\begin{array}{c}99 \\
(66)\end{array}$ & & & 562 & & & & & \\
\hline & $\begin{array}{c}91 \\
60.66)\end{array}$ & & & $\begin{array}{c}545 \\
(73.45)\end{array}$ & & 680 & & & \\
\hline E-re & $\begin{array}{c}16 \\
(10.66)\end{array}$ & & $\begin{array}{c}47 \\
(9.89)\end{array}$ & $\begin{array}{c}116 \\
(15.63)\end{array}$ & $\begin{array}{c}83 \\
(14.51)\end{array}$ & $\begin{array}{c}96 \\
(9.5)\end{array}$ & $\begin{array}{c}20 \\
(13.98)\end{array}$ & $\begin{array}{c}83 \\
(51.55)\end{array}$ & \\
\hline Ent & $\begin{array}{c}21 \\
(14)\end{array}$ & & $\begin{array}{c}74 \\
(15.57)\end{array}$ & $\begin{array}{c}147 \\
(19.81)\end{array}$ & $\begin{array}{c}84 \\
(14.68)\end{array}$ & $\begin{array}{c}167 \\
(16.53)\end{array}$ & $\begin{array}{c}11 \\
(7.69)\end{array}$ & $\begin{array}{c}53 \\
(32.91)\end{array}$ & $\begin{array}{c}231 \\
(17.58)\end{array}$ \\
\hline rlatt & $\begin{array}{c}29 \\
19.33)\end{array}$ & $\begin{array}{c}195 \\
(28.30)\end{array}$ & $\begin{array}{c}82 \\
(17.26)\end{array}$ & $\begin{array}{c}217 \\
(29.24)\end{array}$ & $\begin{array}{c}89 \\
(15.55)\end{array}$ & $\begin{array}{c}211 \\
(20.89)\end{array}$ & $\begin{array}{c}22 \\
(15.38)\end{array}$ & $\begin{array}{c}73 \\
(45.34)\end{array}$ & $\begin{array}{c}306 \\
(23.29)\end{array}$ \\
\hline
\end{tabular}


International Journal of Trend in Scientific Research and Development, Volume 1(4), ISSN: 2456-6470 www.ijtsrd.com

\begin{tabular}{|c|c|c|c|c|c|c|c|c|c|}
\hline Research & $\begin{array}{c}47 \\
(31.33)\end{array}$ & $\begin{array}{c}172 \\
(24.96)\end{array}$ & $\begin{array}{c}93 \\
(19.57)\end{array}$ & $\begin{array}{c}183 \\
(24.66)\end{array}$ & $\begin{array}{c}129 \\
(22.55)\end{array}$ & $\begin{array}{c}215 \\
(21.28)\end{array}$ & $\begin{array}{c}32 \\
(22.37)\end{array}$ & $\begin{array}{c}65 \\
(40.37)\end{array}$ & $\begin{array}{c}312 \\
(23.74)\end{array}$ \\
\hline Teaching & $\begin{array}{c}21 \\
(14)\end{array}$ & $\begin{array}{c}128 \\
(18.57)\end{array}$ & $\begin{array}{l}38 \\
(8)\end{array}$ & $\begin{array}{c}110 \\
(14.82)\end{array}$ & $\begin{array}{c}77 \\
(13.46)\end{array}$ & $\begin{array}{c}85 \\
(8.41)\end{array}$ & $\begin{array}{c}13 \\
(9.09)\end{array}$ & $\begin{array}{c}89 \\
(55.27)\end{array}$ & $\begin{array}{c}187 \\
(14.23)\end{array}$ \\
\hline FTP & $\begin{array}{c}4 \\
(2.66)\end{array}$ & $\begin{array}{c}51 \\
(7.4)\end{array}$ & $\begin{array}{c}21 \\
(4.42)\end{array}$ & $\begin{array}{c}56 \\
(7.54)\end{array}$ & $\begin{array}{c}20 \\
(3.49)\end{array}$ & $\begin{array}{c}34 \\
(3.36)\end{array}$ & $\begin{array}{c}1 \\
(0.69)\end{array}$ & $\begin{array}{c}41 \\
(25.46)\end{array}$ & $\begin{array}{c}76 \\
(5.78)\end{array}$ \\
\hline $\begin{array}{l}\text { Telenet } \\
\text { (remote login) }\end{array}$ & $\begin{array}{c}4 \\
(2.66)\end{array}$ & $\begin{array}{c}50 \\
(7.25)\end{array}$ & $\begin{array}{c}11 \\
(2.31)\end{array}$ & $\begin{array}{c}48 \\
(6.46)\end{array}$ & $\begin{array}{c}17 \\
(2.97)\end{array}$ & $\begin{array}{c}26 \\
(2.57)\end{array}$ & $\begin{array}{c}4 \\
(2.79)\end{array}$ & $\begin{array}{c}35 \\
(21.73)\end{array}$ & $\begin{array}{c}65 \\
(4.95)\end{array}$ \\
\hline $\begin{array}{l}\text { E-journal } \\
\text { archives }\end{array}$ & $\begin{array}{c}7 \\
(4.66)\end{array}$ & $\begin{array}{c}55 \\
(7.98)\end{array}$ & $\begin{array}{l}19 \\
(4)\end{array}$ & $\begin{array}{l}52 \\
(7)\end{array}$ & $\begin{array}{c}29 \\
(5.06)\end{array}$ & $\begin{array}{c}46 \\
(4.55)\end{array}$ & $\begin{array}{c}6 \\
(4.19)\end{array}$ & $\begin{array}{c}29 \\
(18.01)\end{array}$ & $\begin{array}{c}81 \\
(6.16)\end{array}$ \\
\hline Others & $\begin{array}{c}3 \\
(2)\end{array}$ & $\begin{array}{c}13 \\
(1.88)\end{array}$ & $\begin{array}{c}16 \\
(3.36)\end{array}$ & $\begin{array}{c}19 \\
(2.56)\end{array}$ & $\begin{array}{c}13 \\
(2.27)\end{array}$ & $\begin{array}{c}27 \\
(2.27)\end{array}$ & $\begin{array}{c}2 \\
(1.39)\end{array}$ & $\begin{array}{c}3 \\
(1.86)\end{array}$ & $\begin{array}{c}32 \\
(2.44)\end{array}$ \\
\hline
\end{tabular}

Table 7 Distributions of users according to the type of library, gender, category and their replies with regard to the Internet services used

Note: Figures in parenthesis indicate percentages. Users are permitted to tick more than one answer

Table 7 shows, that majority of the users (69.94\%) of them are using the E-mail service, 69.86 per cent of them are using World wide web (WWW), 23.74 per cent of them are using for research, 23.29 per cent of them are using Internet for Chatting, 17.58 per cent of them are using for entertainment, 15.14 per cent of them are using Internet for E-resources , 14.23 per cent of them are using for teaching , 6.16 per cent of them are using Internet for e-journal archives, 5.78 per cent of them are using F T P , 4.95 per cent of them are using Telenet (remote login) and the remaining 2.44 per cent of them are using other services.

\subsection{Satisfaction with Internet facility}

A question has been put to the users to know their satisfaction with Internet facility. The responses given by them are shown in Table 8 .

\begin{tabular}{|l|c|c|c|c|c|c|c|c|c|}
\hline \multirow{2}{*}{ Response } & \multicolumn{3}{|c|}{ Type of library } & \multicolumn{2}{c|}{ Gender } & \multicolumn{3}{c|}{ Category } & Total \\
\cline { 2 - 8 } & U E & O P E & N P E & M & F & U G & P G & F M & \\
\hline Yes & 79 & 383 & 202 & 358 & 306 & 466 & 83 & 115 & 664 \\
& $(52.67)$ & $(55.59)$ & $(42.53)$ & $(48.25)$ & $(53.50)$ & $(46.14)$ & $(84.04)$ & $(71.43)$ & $(50.53)$ \\
\hline \multirow{2}{*}{ No } & 71 & 306 & 273 & 384 & 266 & 544 & 60 & 46 & 650 \\
& $(47.33)$ & $(44.41)$ & $(57.47)$ & $(51.75)$ & $(46.50)$ & $(53.86)$ & $(41.96)$ & $(28.57)$ & $(49.47)$ \\
\hline Total & $\mathbf{1 5 0}$ & $\mathbf{6 8 9}$ & $\mathbf{4 7 5}$ & $\mathbf{7 4 2}$ & $\mathbf{5 7 2}$ & $\mathbf{1 0 1 0}$ & $\mathbf{1 4 3}$ & $\mathbf{1 6 1}$ & $\mathbf{1 3 1 4}$ \\
& $(\mathbf{1 0 0 . 0 0})$ & $\mathbf{( 1 0 0 . 0 0 )}$ & $\mathbf{( 1 0 0 . 0 0 )}$ & $\mathbf{( 1 0 0 . 0 0 )}$ & $(\mathbf{1 0 0 . 0 0 )}$ & $\mathbf{( 1 0 0 . 0 0 )}$ & $\mathbf{( 1 0 0 . 0 0 )}$ & $\mathbf{( 1 0 0 . 0 0 )}$ & $(\mathbf{1 0 0 . 0 0})$ \\
\hline
\end{tabular}

Table 8 Distributions of users according to the type of library, gender, category and their replies with regard to their satisfaction with Internet facility

Note: Figures in parenthesis indicate percentages 


\begin{tabular}{|c|c|c|c|}
\hline $\begin{array}{l}x^{2}(U G-P G): \\
8.245\end{array}$ & df: 1 & $\mathrm{TV}: 3.841$ & $\begin{array}{l}\text { Sig at } 0.05 \\
\text { level }\end{array}$ \\
\hline $\begin{array}{l}x^{2}(\mathrm{UG}-\mathrm{FM}): \\
9.967\end{array}$ & df: 1 & TV:3.841 & $\begin{array}{l}\text { Sig at } 0.05 \\
\text { level }\end{array}$ \\
\hline $\begin{array}{l}x^{2}(\mathrm{PG}-\mathrm{FM}): \\
5.871\end{array}$ & df: 1 & $\mathrm{TV}: 3.841$ & $\begin{array}{l}\text { Sig at } 0.05 \\
\text { level }\end{array}$ \\
\hline$x^{2}(\mathrm{UE}-$ OPE): 19 & df: 1 & TV:3.841 & $\begin{array}{l}\text { Sig at } 0.05 \\
\text { level }\end{array}$ \\
\hline $\begin{array}{l}x^{2}(\mathrm{UE} \\
- \text { NPE): } 3.089\end{array}$ & df: 1 & TV:3.841 & $\begin{array}{l}\text { N Sig at } \\
0.05 \text { level }\end{array}$ \\
\hline $\begin{array}{l}x^{2} \text { (OPE } \\
- \text { NPE): } 4.985\end{array}$ & df: 1 & TV:3.841 & $\begin{array}{l}\text { Sig at } 0.05 \\
\text { level }\end{array}$ \\
\hline $\begin{array}{l}x^{2}(M \\
-F): 6.987\end{array}$ & $\mathrm{df}: 1$ & $\mathrm{TV}: 3.841$ & $\begin{array}{l}\text { Sig at } 0.05 \\
\text { level }\end{array}$ \\
\hline
\end{tabular}

It is evident from Table 8 that half of the users (50.53\%) replied that they are satisfied with Internet facility and the remaining 49.47 per cent of them replied negatively.

It is obvious from Table 8 that there is a significant difference in their replies with regard to their satisfaction with Internet facility between the users of undergraduates and postgraduates on one hand, and undergraduates and faculty members on the other hand. It is proved by the Chi-square values which are significant at 0.05 level with one degree of freedom, which means more number of postgraduates, and faculty members replied that they are satisfied with Internet facility compared to undergraduates.

It is also evident from the table that there is a significant difference in their replies with regard to their satisfaction with Internet facility between the users of postgraduates and faculty members. It is indicated by the Chi-square value which is significant at 0.05 level with one degree of freedom, which means more number of postgraduates replied that they are satisfied with Internet facility compared to faculty members.

It can also be seen from the table that there is a significant difference in their replies with regard to their satisfaction with Internet facility between the users of University engineering college libraries and old Private engineering college libraries on one hand, and University engineering college libraries and new Private engineering college libraries on the other hand. It is proved by the Chi-square values which are significant at 0.05 level with one degree of freedom, which means more number of users of old Private engineering college libraries replied that they are satisfied with Internet facility compared to users of new Private engineering college libraries and University engineering college libraries. However, there is no significant difference in their satisfaction with Internet facility between the users of University engineering college libraries and new Private engineering college libraries. It is indicated by the Chi-square value which is not significant at 0.05 level with one degree of freedom.

It is also noticed that there is a significant difference between men and women users with regard to their satisfaction with Internet facility. It is evidenced by the Chi-square value which is significant at 0.05 level with one degree of freedom, which means more number of women users replied that they are satisfied with Internet facility compared to the men users.

\subsection{Problems faced in using Internet}

Users face many problems in using Internet. Hence, a question has been put to the users to know the problems encountered in using Internet. The responses given by them are shown in Table 9 .

\begin{tabular}{|c|c|c|c|c|c|c|c|c|c|}
\hline \multirow{2}{*}{ Problems } & \multicolumn{3}{|c|}{ Type of library } & \multicolumn{2}{|c|}{ Gender } & \multicolumn{3}{|c|}{ Category } & \multirow{2}{*}{$\begin{array}{r}\text { Total } \\
\mathrm{N}=1314\end{array}$} \\
\hline & $\begin{array}{c}\mathbf{U} \mathbf{E} \\
\mathbf{n}=\mathbf{1 5 0}\end{array}$ & $\begin{array}{l}\text { O P E } \\
n=689\end{array}$ & $\begin{array}{l}\text { N P E } \\
n=475\end{array}$ & $\begin{array}{c}M \\
n=742\end{array}$ & $\underset{n=572}{F}$ & $\underset{n=1010}{\mathbf{U} G}$ & $\begin{array}{c}P G \\
n=143\end{array}$ & $\begin{array}{c}\mathbf{F} M \\
\mathrm{n}=161\end{array}$ & \\
\hline $\begin{array}{l}\text { Insufficient } \\
\text { number of } \\
\text { terminals }\end{array}$ & $\begin{array}{c}53 \\
(35.33)\end{array}$ & $\begin{array}{c}174 \\
(25.22)\end{array}$ & $\begin{array}{c}120 \\
(25.26)\end{array}$ & $\begin{array}{c}198 \\
(26.68)\end{array}$ & $\begin{array}{c}149 \\
(26.04)\end{array}$ & $\begin{array}{c}258 \\
(25.54)\end{array}$ & $\begin{array}{c}38 \\
(26.57)\end{array}$ & $\begin{array}{c}51 \\
(31.67)\end{array}$ & $\begin{array}{c}347 \\
(26.41)\end{array}$ \\
\hline $\begin{array}{l}\text { Low } \\
\text { bandwidth }\end{array}$ & $\begin{array}{c}49 \\
(32.66)\end{array}$ & $\begin{array}{c}207 \\
(30.04)\end{array}$ & $\begin{array}{c}150 \\
(31.57)\end{array}$ & $\begin{array}{c}261 \\
(35.17)\end{array}$ & $\begin{array}{c}145 \\
(25.34)\end{array}$ & $\begin{array}{c}309 \\
(30.59)\end{array}$ & $\begin{array}{c}46 \\
(32.16)\end{array}$ & $\begin{array}{c}51 \\
(31.67)\end{array}$ & $\begin{array}{c}406 \\
(30.90)\end{array}$ \\
\hline $\begin{array}{l}\text { Lack of } \\
\text { printout }\end{array}$ & $\begin{array}{c}33 \\
(22)\end{array}$ & $\begin{array}{c}134 \\
(19.44)\end{array}$ & $\begin{array}{c}84 \\
(17.68)\end{array}$ & $\begin{array}{c}149 \\
(20.08)\end{array}$ & $\begin{array}{c}102 \\
(17.83)\end{array}$ & $\begin{array}{c}191 \\
(18.91)\end{array}$ & $\begin{array}{c}18 \\
(12.58)\end{array}$ & $\begin{array}{c}42 \\
(26.08)\end{array}$ & $\begin{array}{c}251 \\
(19.10)\end{array}$ \\
\hline
\end{tabular}


International Journal of Trend in Scientific Research and Development, Volume 1(4), ISSN: 2456-6470 www.ijtsrd.com

\begin{tabular}{|c|c|c|c|c|c|c|c|c|c|}
\hline Facility & & & & & & & & & \\
\hline $\begin{array}{l}\text { Privacy } \\
\text { problem }\end{array}$ & $\begin{array}{c}20 \\
(13.33)\end{array}$ & $\begin{array}{c}74 \\
(1074)\end{array}$ & $\begin{array}{c}53 \\
(11.15)\end{array}$ & $\begin{array}{c}76 \\
(10.24)\end{array}$ & $\begin{array}{c}71 \\
(12.41)\end{array}$ & $\begin{array}{c}123 \\
(12.17)\end{array}$ & $\begin{array}{c}16 \\
(11.18)\end{array}$ & $\begin{array}{c}8 \\
(4.96)\end{array}$ & $\begin{array}{c}147 \\
(11.19)\end{array}$ \\
\hline Virus transfer & $\begin{array}{c}15 \\
(10)\end{array}$ & $\begin{array}{c}97 \\
(14.07)\end{array}$ & $\begin{array}{c}91 \\
(19.15)\end{array}$ & $\begin{array}{c}122 \\
(16.44)\end{array}$ & $\begin{array}{c}81 \\
(14.16)\end{array}$ & $\begin{array}{c}158 \\
(15.64)\end{array}$ & $\begin{array}{c}32 \\
(22.37)\end{array}$ & $\begin{array}{c}13 \\
(8.07)\end{array}$ & $\begin{array}{c}203 \\
(15.45)\end{array}$ \\
\hline $\begin{array}{l}\text { Power } \\
\text { fluctuation }\end{array}$ & $\begin{array}{c}21 \\
(14)\end{array}$ & $\begin{array}{c}118 \\
(17.12)\end{array}$ & $\begin{array}{c}75 \\
(15.78)\end{array}$ & $\begin{array}{c}117 \\
(10.37)\end{array}$ & $\begin{array}{c}97 \\
(16.95)\end{array}$ & $\begin{array}{c}160 \\
(15.84)\end{array}$ & $\begin{array}{c}20 \\
(13.98)\end{array}$ & $\begin{array}{c}34 \\
(21.11)\end{array}$ & $\begin{array}{c}214 \\
(16.29)\end{array}$ \\
\hline $\begin{array}{l}\text { Lack of } \\
\text { training }\end{array}$ & $\begin{array}{l}12 \\
(8)\end{array}$ & $\begin{array}{c}65 \\
(9.43)\end{array}$ & $\begin{array}{c}57 \\
(12)\end{array}$ & $\begin{array}{c}77 \\
(10.37)\end{array}$ & $\begin{array}{c}57 \\
(9.96)\end{array}$ & $\begin{array}{c}107 \\
(10.59)\end{array}$ & $\begin{array}{c}20 \\
(13.98)\end{array}$ & $\begin{array}{c}7 \\
(4.34)\end{array}$ & $\begin{array}{c}134 \\
(10.20)\end{array}$ \\
\hline $\begin{array}{l}\text { Insufficient } \\
\text { time slots }\end{array}$ & $\begin{array}{c}24 \\
(16)\end{array}$ & $\begin{array}{c}102 \\
(14.80)\end{array}$ & $\begin{array}{c}82 \\
(17.26)\end{array}$ & $\begin{array}{c}125 \\
(16.84)\end{array}$ & $\begin{array}{c}83 \\
(14.51)\end{array}$ & $\begin{array}{c}154 \\
(15.24)\end{array}$ & $\begin{array}{c}30 \\
(20.97)\end{array}$ & $\begin{array}{c}24 \\
(14.9)\end{array}$ & $\begin{array}{c}208 \\
(15.83)\end{array}$ \\
\hline Others & $\begin{array}{c}7 \\
(4.66)\end{array}$ & $\begin{array}{c}21 \\
(3.04)\end{array}$ & $\begin{array}{c}21 \\
(4.42)\end{array}$ & $\begin{array}{c}38 \\
(5.12)\end{array}$ & $\begin{array}{c}11 \\
(1.92)\end{array}$ & $\begin{array}{c}47 \\
(4.65)\end{array}$ & $\begin{array}{c}2 \\
(1.39)\end{array}$ & 0 & $\begin{array}{c}49 \\
(3.73)\end{array}$ \\
\hline
\end{tabular}

Table 9 Distributions of users according to the type of library, gender, category and problems faced in using Internet

Note: Figures in parenthesis indicate percentages. Users are permitted to tick more than one answer

Table 9 shows, a high percentage $(30.9 \%)$ of the users have faced the problem of low bandwidth, 26.41 per cent insufficient number of terminals, 19.10 per cent lack of printout facility, 16.29 per cent Power fluctuation, 15.83 per cent insufficient time slots, 15.45 per cent virus problem, 11.19 per cent privacy problem, 10.20 per cent lack of training and the remaining 3.73 per cent other problems.

\section{FINDINGS OF THE STUDY}

1. Majority of the users $(77.55 \%)$ replied that their libraries are providing Internet facility.

2. More number of faculty members and postgraduates replied that their libraries are providing Internet facility compared to undergraduates.

3. A high percentage of users $(40.11 \%)$ use Internet most frequently at their respective libraries.

4. Over a one third of users $(36.91 \%)$ replied that they are using Internet 2 to 3 times in a week.

5. Faculty members are more frequently using Internet compared to postgraduates.

6. The users of old Private engineering college libraries are more frequently using Internet compared to users of University engineering college libraries.
7. Users of University engineering college libraries are more frequently using Internet compared to the users of new private engineering college libraries.

8. Men users are more frequently using Internet compared to the women users.

9. A high percentage of users $(41.70 \%)$ replied that they have been using the Internet from 1-2 Years.

10. The users of old Private engineering college libraries are having more experience in using Internet compared to users of new Private engineering college libraries, and University engineering college libraries.

11. Majority of the users (65.54\%) are using the Google chrome as an Internet browser.

12. Most of the users (92.54\%) replied that Google is the preferred search engine.

13. Majority of the users $(69.94 \%)$ of them are using the E-mail service.

14. Half of the users $(50.53 \%)$ replied that they are satisfied with Internet facility.

15. More number of postgraduates, and faculty members replied that they are satisfied with Internet facility compared to undergraduates.

16. More number of users of old Private engineering college libraries replied that they are satisfied with 
Internet facility compared to users of new Private engineering college libraries and University engineering college libraries.

17. More number of women users replied that they are satisfied with Internet facility compared to the men users.

18. A high percentage $(30.9 \%)$ of the users has faced the problem of low bandwidth.

\section{SUGGESTIONS}

Based on the findings of the study, the following suggestions are put forward to improve the use of the Internet among the faculty and students in engineering colleges in S V University area. The study reveals that nearly half of the (49.47) users are not satisfied with Internet facility. Hence, based on this study, a number of recommendations applicable to engineering college libraries can be made:

- To provide Internet services efficiently and effectively, the number of computers should be increased in the library and departments.

- The computer centres, departments and library should acquire high-speed Internet connectivity to overcome the problem of slow downloading.

- User training must be given for the proper exploitation of Internet.

- The staff of the library should be trained in ICT skills so that they can assist the users when they face any problem in accessing Internet.

- The library, computer labs and departments should provide printing facilities for Internet resources free or at a minimum cost.

\section{CONCLUSION}

Internet is now a most effective and user-friendly technology for accessing information in all fields. In engineering colleges, the users like students, faculty members have highly dependent on Internet for accessing information and exchange their ideas in their respective disciplines .The electronic journals and e- databases available in the Internet are widely used by the user community of engineering education. Hence, a free Internet service with increasing number of subscribed e- journals and e-databases facility is of great importance to meet the emerging needs for the users of engineering education system.

\section{REFERENCES}

[1] Sreenivasulu, M and M R Nagabhushanam. "The use of Internet and online databases at National Institute of Fashion Technology, Kannur: A case study". International Journal of Library and Information Studies, 3 (2013): 1-8. Print.

[2] Madhuri, A J. "Usage of Internet services by engineering students in Tirupati: A study". International Journal of Library and Information Studies, 2 (2012): 74-88. Print.

[3] Thanuskodi, S. "Use of Internet and electronic resources among medical professionals with special reference to Tamil Nadu: A case study". SRELS Journal of Information Management, 49 (2012): 281-292. Print.

[4] Chinnasamy, K and Lakshmi Sankari. "Usage of Internet services and resources in the college Libraries of Salem District: A study". International Journal of Library and Information Studies, 2 (2011): 16-26. Print.

[5] Fayaz, Ahmad Loan. "Internet use by rural and urban college students: A comparative study". DESIDOC Journal of Library \&Information Technology, 31 (2011): 431-436. Print.

[6] Sarasvathy, P and D Giddaiah. "Internet and its use in University Library-Mysore: A case study". SRELS Journal of Information Management, 47 (2010): 321-324. Print.

[7] Manjunath and Mallinath. "Use of CD-ROMs and Internet resource by the students in JNN College of Engineering Shimoga: A survey". SRELS Journal of Information Management, 45 (2008): 235-242. Print.

[8] Suresh, Jange and K Lalitha Sámi. "Influence of Internet on Library and Information Centres of National Institutes of Technology in India". Annals of Library and Information Studies, 53 (2006): 184-197. Print.

[9] Shabani, A and F Mahdieh Najafabadi. "The role of the Internet in locating information by academic members in Najafabad Azad University". Health Information Management, 3 (2006): 13-18. Print. 